\title{
42. THE NEW ENGLAND SEAMOUNTS: TESTING ORIGINS ${ }^{1}$
}

\author{
Peter R. Vogt, Naval Research Laboratory, Washington, D.C. \\ and \\ Brian E. Tucholke, Lamont-Doherty Geological Observatory of Columbia University, Palisades, New York
}

\section{INTRODUCTION}

Two Leg 43 sites were drilled along the New England (Kelvin) Seamount Chain to determine the age and nature of volcanism, and to penetrate to original oceanic crust if possible. Site 382 was drilled at the base of Nashville Seamount near the southeastern end of the seamount chain, and drilling at Site 385 penetrated the lower flank of Vogel Seamount, about $450 \mathrm{~km}$ northwest of Nashville Seamount. At both sites we were able to date the final stages of volcanism, but at neither site did drilling fully penetrate the seamounts' volcaniclastic apron; thus, the times of initiation of volcanism and the age of the underlying crust remain untested.

Knowing the age patterns of volcanism along the seamount chain is crucial to testing various hypotheses on the origin of the volcanoes. If the seamount chain formed as a result of northwest motion of the North America plate over a fixed mantle hot-spot (Morgan, 1971, 1972) or along a southeastward-propagating fracture, the seamounts should become progressively older from southeast to northwest. If, on the other hand, the volcanoes erupted along a fault trace (Uchupi et al., 1970; Le Pichon and Fox, 1971), volcanism could have been simultaneous, episodic, or migratory, depending upon the timing and orientation of associated stress patterns. In this paper, we review pertinent age data to test the hypotheses of migratory and coeval volcanism. The discussion also draws on published data regarding midplate seamounts and volcanic chains in the world ocean. Although available data do not clearly favor one origin over another, constraints can be placed on the ages of volcanism, and these constraints should be used to guide future sampling programs.

\section{AGES OF VOLCANISM}

In Figure 1 we have plotted basement and seamount age data and other relevant information as a function of distance from Congress Seamount, the most southeasterly seamount along the trend of the New England (Kelvin) Seamount Chain (Figure 2). Various hypotheses for the origin of the seamounts may be evaluated with reference to this figure, in which seamount and borehole positions are projected onto a segment of a small circle about Morgan's Cretaceous pole of movement of the North America plate over the mantle $\left(60.7^{\circ} \mathrm{N}, 57.8^{\circ} \mathrm{E}\right.$; W.J. Morgan, personal communication, 1976). The

\footnotetext{
${ }^{1}$ Contribution No. 2674 of Lamont-Doherty Geological Observatory.
}

White Mountain Igneous Province to the northwest and the Corner Seamounts to the east also are projected onto this small circle, because these two features have been proposed as manifestations of a "New England Hot Spot"; they were generated before and after the New England Seamounts, respectively (Coney, 1971; McGregor and Krause, 1972; Vogt, 1973).

Considering the age of Nashville Seamount (Site 382) in combination with other constraints on plate motions in the Cretaceous, W.J. Morgan (personal communication, 1976) suggested a plate/mantle rotation rate of $0.38 \% \mathrm{~m} . y_{\text {. }}$, or about $4 \mathrm{~cm} /$ year along the New England Seamount chain. On this basis, the initiation or main phase of volcanic activity at Vogel Seamount should have occurred about $11 \mathrm{~m} . \mathrm{y}$. before the corresponding activity at Nashville Seamount. As can be seen in Figure 1 , the available data neither demonstrate nor preclude such an age difference.

The volcaniclastic breccias recovered at the Leg 43 sites appear to record volcanic events on the adjacent seamounts, and because alteration of the enclosed basaltic clasts is extremely variable, some of the clasts are thought to have been displaced, during the volcanic events, from pre-existing volcanic units on the crest and flanks of the seamount. At Site 382 beside Nashville Seamount, the latest significant volcanism occurred as late as early Campanian (74 to 78 m.y.B.P. on the van Hinte [1976] time scale), as indicated by the upper volcaniclastic breccia (Figure 3). The latter part of the main phase of Nashville construction, however, is probably represented by basalt clasts in the lower breccia unit, because their high vesicularity indicates that basalt extrusion was in water less than 1000 meters deep (Moore, 1965). Radiometric ages on these clasts range from 79 \pm 4 to $88.3 \pm 5.7 \mathrm{~m} . \mathrm{y}$.; the greater age probably is the more reliable (Houghton et al., this volume). No ages were obtained for basalt clasts in the upper breccia because of their extensive alteration, but this alteration may in itself indicate that the clasts were exposed for a longer period on the seamount before being displaced to the drill site, and that their ages are comparable to those of clasts in the deeper breccia. The time at which the basalt clasts in the lower breccia were displaced from Nashville Seamount to Site $\mathbf{3 8 2}$ is difficult to determine. Provided there is no hiatus between the lower breccia and the overlying lower Campanian claystones and siltstones, the volcanic event triggering deposition of the breccias may have occurred near the Santonian/Campanian boundary (78 m.y. on the van Hinte [1976] time scale). It is thus possible that some of the radiometrically dated clasts were erupted during this event, and not de- 


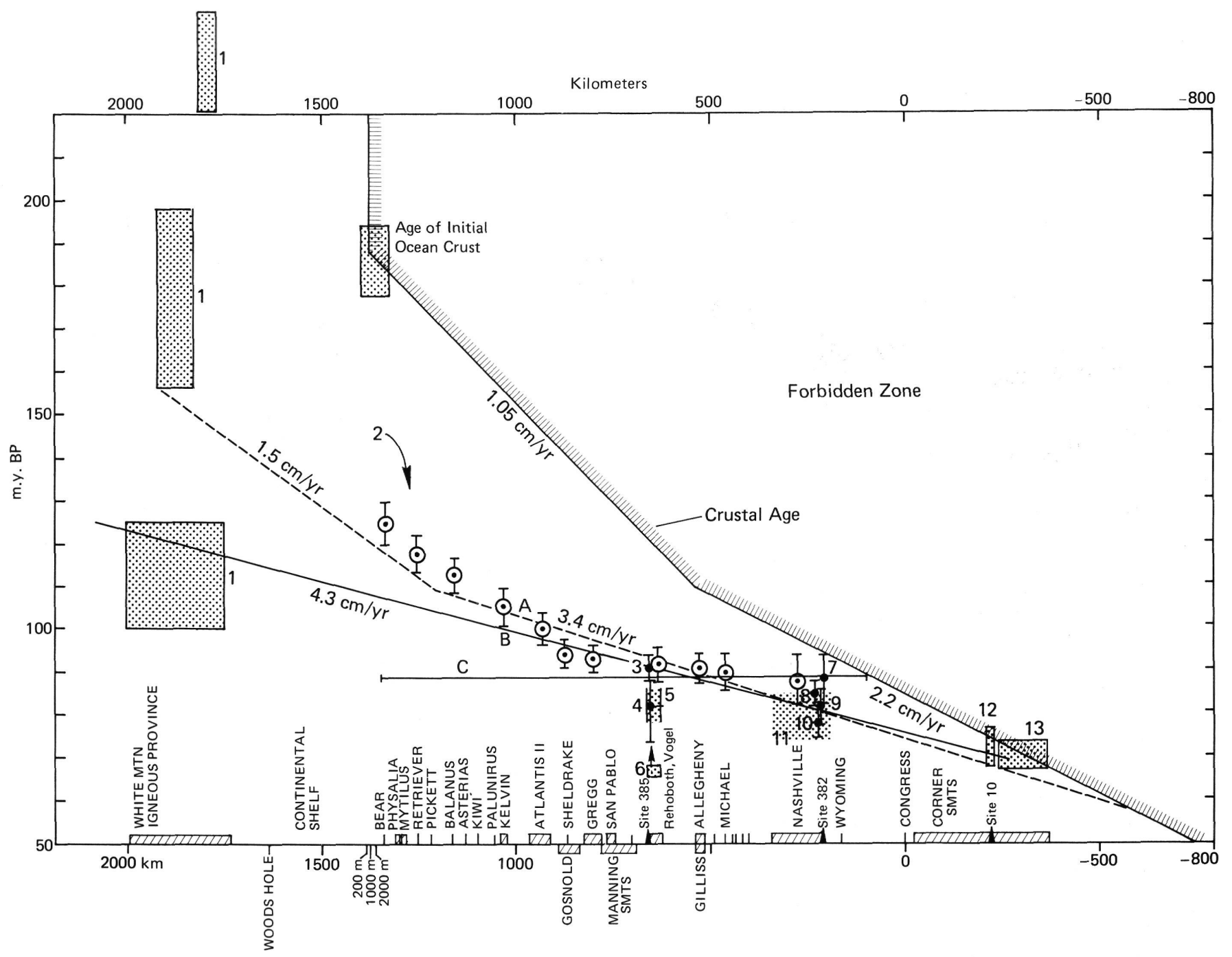

Figure 1. Age dates and other relevant information projected on a line passing south of the Corner Seamounts, along the New England Seamounts, and south of the White Mountain igneous province (Figure 2). Line is portion of small circle about pole of Cretaceous motion between North America plate and mantle $\left(60.7^{\circ} \mathrm{N}, 57.8^{\circ} \mathrm{E} ; \mathrm{W} . \mathrm{J}\right.$. Morgan, personal communication, 1976). (1) Groups of radiometric ages in White Mountain igneous province (Foland and Faul, 1977). (2) Radiometric ages of basalts sampled along the New England Seamounts (Houghton, et al., 1977; Duncan and Houghton, 1977, Houghton, 1978). (3) and (4) $K$-Ar hornblende crystallization ages from Vogel Seamount-site 385 (Houghton et al., this volume). (5) Very uncertain Coniacian-Santonian age from benthic foraminifers in volcaniclastic sediment above breccia at Site 385. (6) Mid-Maestrichtian non-volcanogenic sediments at Site 385 mark younger limit of age of volcanism. (7) $K$-Ar hornblende crystallization age for lower breccia at Site 382 (Houghton et al., this volume). (8) $\mathrm{K}$ - $\mathrm{Ar}$ whole-rock age, (9) whole-rock ${ }^{40} \mathrm{Ar} /{ }^{39} \mathrm{Ar}$ total gas age, and $(10){ }^{40} \mathrm{Ar} /{ }^{39} \mathrm{Ar}$ argon-retention age, all determined for lower breccia at Site 382 (Houghton et al., this volume). (11) Paleontologic age of volcaniclastic sediments at Site 382, with u/l Campanian boundary interpolated from van Hinte (1976) and Obradovich and Cobban (1975). (12) Lower Maestrichtian to lower/middle Campanian ash layers at Site 10, possibly derived from Corner Seamounts (Peterson, Edgar, et al., 1970). (13) Crustal ages for northeastern Corner Seamounts, as extrapolated from Cande and Kristoffersen (1977). "Crustal age'" line based on Vogt and Einwich, this volume. Apparent spreading rates along small circle are less than rates derived by Vogt and Einwich along plate flow lines further to the south. "Forbidden zone" means no seamounts can predate the crust on which they stand. Interpretations: Models $A$ and $B$ show reasonable rates of Cretaceous plate motion over a stationary hot spot (W. J. Morgan, personal communication, 1976). Model A has slower pre-110 m.y.B.P. motion, as in basement age curve, and intersects middle group of White Mountain ages. Model B is linear, intersects youngest group of White Mountain ages. In models $A$ and $B$, rates of motion along lines connected to White Mountain ages are minimums. White Mountain ages are projected onto small circle. Model C has New England Seamounts formed simultaneously at about 89 m.y.B.P. All models refer to main phase of volcano construction; some eruptions probably continued for 5 to 10 million years afterward. Vertical extent of stippled patterns includes actual time length of formation plus probable uncertainties in stratigraphic range and uncertainties in time-scale calibration. 


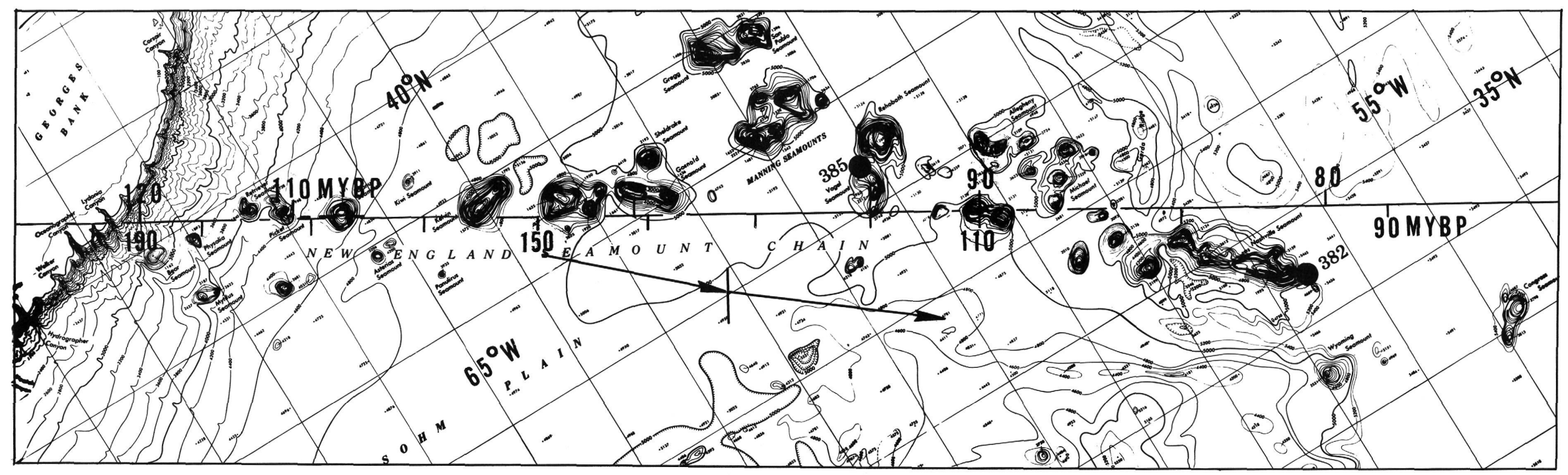

Figure 2. Bathymetry along New England Seamounts, with estimated age of oceanic crust (lower scale) and seamounts (upper scale)(isobaths in uncorrected meters: Anonymous, 1973). The seamount age scale corresponds to Model A in Figure 1. Scale line is portion of small circle about independently derived Cretaceous pole of motion $\left(60.7^{\circ} \mathrm{N}, 57.8^{\circ} \mathrm{E}\right)$ of North America plate over mantle (W. J. Morgan, personal communication, 1976). Locations of seamounts were projected onto scale line in constructing the age-distance graph of Figure 1. Arrows show fracture-zone trends in adjacent crust (from Schouten and Klitgord, 1977). 
SITE 382

NASHVILLE SEAMOUNT

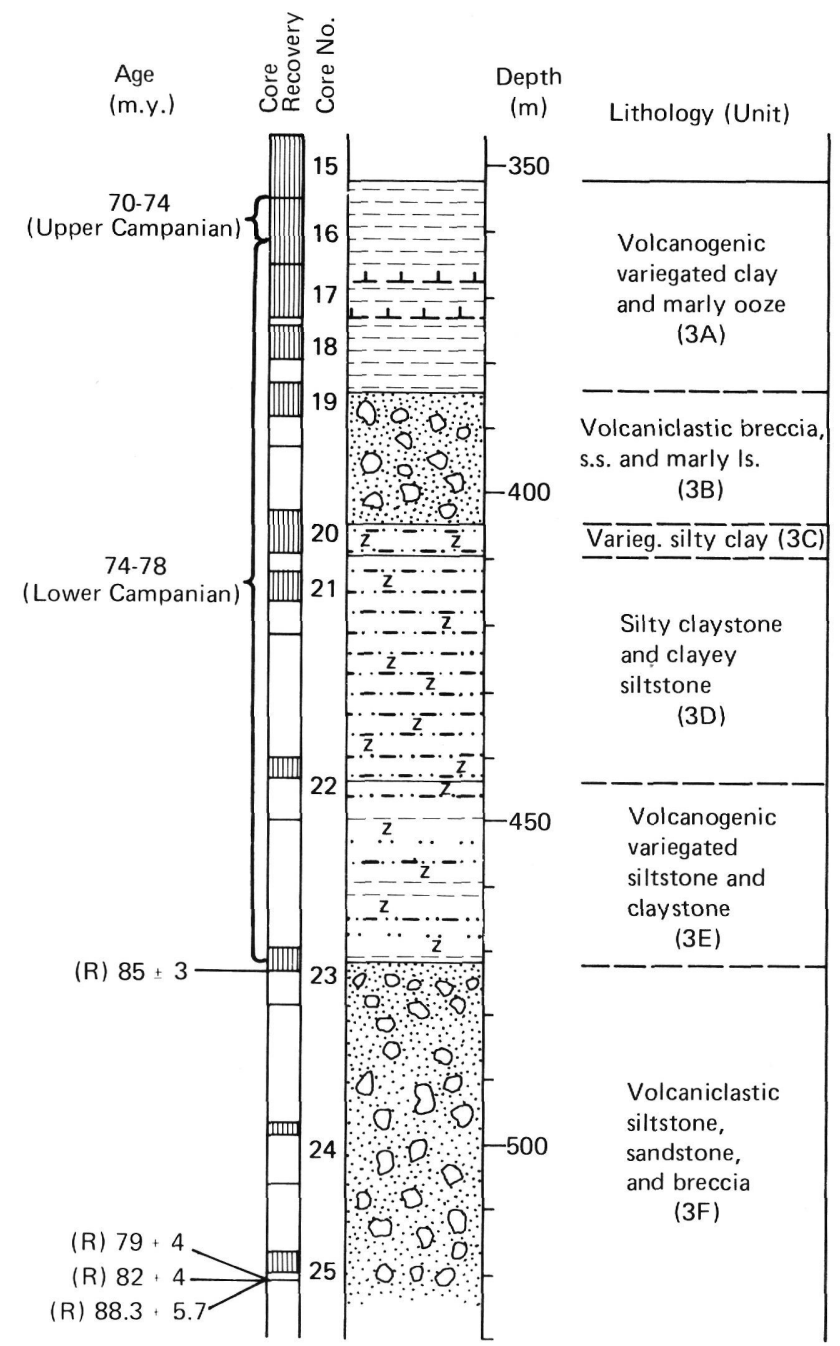

SITE 385

VOGEL SEAMOUNT

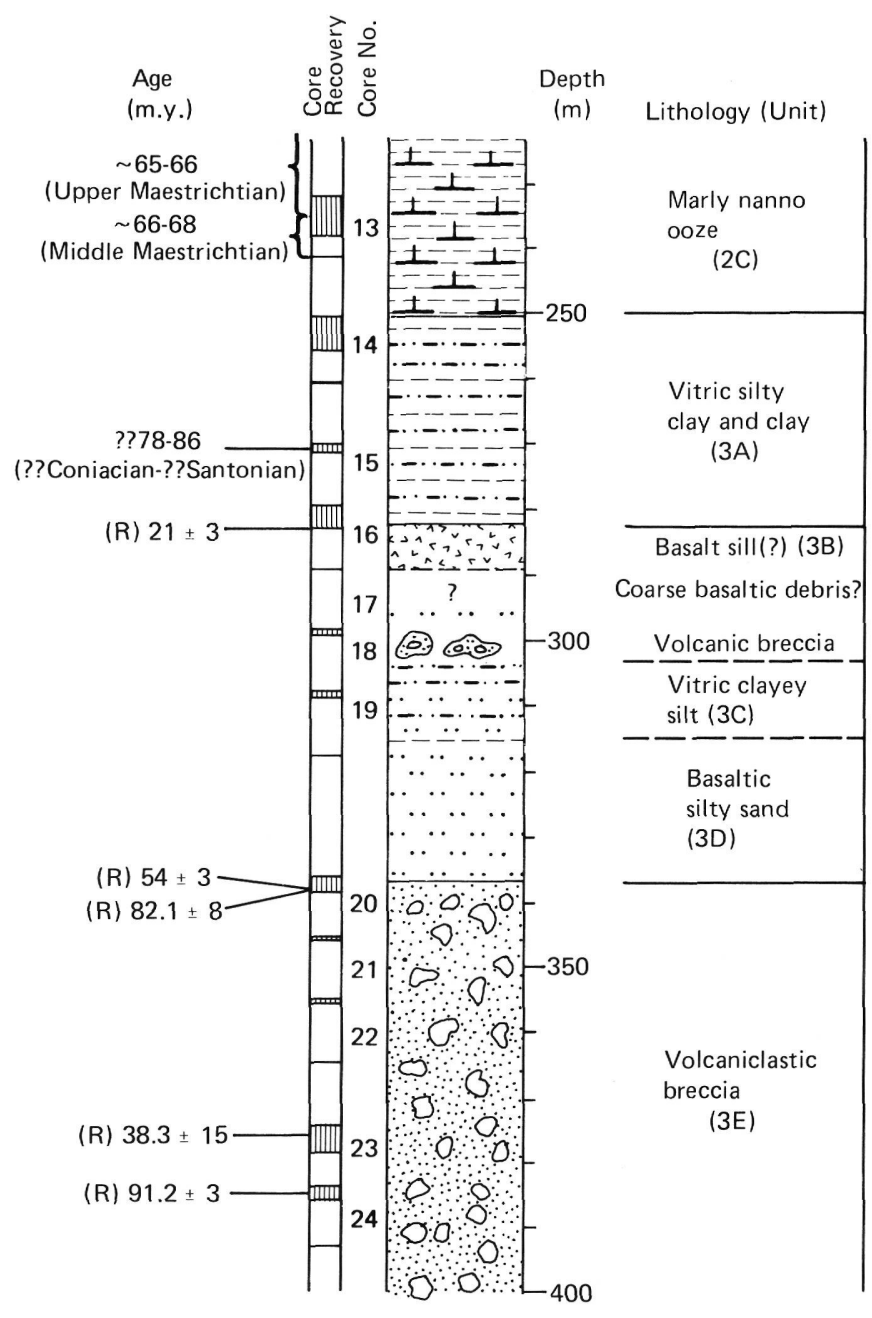

Figure 3. Volcanogenic sediments (lithologic Unit 3) penetrated at Sites 382 and 385. Ages at left are based on van Hinte (1976) time scale, and radiometric ages on basalt clasts $(R)$ are from Houghton et al., (this volume).

rived from pre-existing volcanic units. Assuming that this event represents the final stage of the main volcanic phase at Nashville, and that radiometric ages of the clasts accurately reflect the timing of main-phase volcanism, we can date the formation of Nashville Seamount at about 80 to 94 m.y.B.P. Seamount formation cannot predate about 95 m.y., our estimate for the crustal age at this site (Figures 1 and 2; see also Vogt and Einwich, this volume).

At Vogel Seamount (Site 385) the age dating problem is more difficult. The earliest reliable paleontologic date is middle Maestrichtian (66 to $68 \mathrm{~m} . \mathrm{y}$.) for the marly ooze at the bottom of Core 13. Between the marly ooze and the breccia in Core 20 lies a volcanogenic sediment unit similar to the Campanian sediment at Site 382 (Figure 3). The lithology of the sediment may reflect the waning phases of volcanism at Vogel Seamount, possibly with contributions from nearby volcanoes, such as Rehoboth Seamount. The cumulative thickness of these volcanogenic sediments (excluding basalt in Core 16 and breccia fragments in Sample 18, CC) is less than 85 meters. Similar sediments at Nashville Seamount were deposited rapidly (at least $23 \mathrm{~m} / \mathrm{m} . \mathrm{y}$. excluding "instantaneously" deposited breccias); thus, the volcanogenic sediments above the basaltic breccia at Vogel Seamount are unlikely to represent more than a few million years. If there is no hiatus between the marly ooze and the volcanogenic sediments, or within the volcanogenic sediments, then the volcanic activity at Vogel Seamount probably lasted into the late Campanian. If there also is no hiatus between the volcanogenic sediments and the underlying breccia, even the main phase of volcanism at Vogel Seamount could have lasted into the late Campanian, making it younger than Nashville Seamount, in strong contradiction to the hotspot hypothesis. 
The radiometric age dates on basalt clasts in the breccia at Site 385 suggest an error in this line of reasoning, however. Of the two reasonable ages, $91.3 \pm 3$ and 82.1 $\pm 8 \mathrm{~m} . \mathrm{y}$., the older one is considered more trustworthy (Houghton et al., this volume), and it indicates a date of mid-Turonian to late Cenomanian, some 20 to $25 \mathrm{~m}$.y. older than the age extrapolated from sediment accumulation rates. Clearly, if the radiometric dates are even reasonably correct, hiatuses probably exist between Core 13 (Maestrichtian ooze) and the breccias in Core 20.

If a hiatus exists immediately below the marly chalks in Core 13, the volcanogenic sediments at Site 385 may be substantially older than upper Campanian. This idea receives some support from tiny, agglutinated benthic foraminifers recovered in Core 14; these resemble Coniacian-Santonian fauna found in the Pacific (Krasheninnikov, 1973, 1974), and may be of similar age. Unfortunately, such foraminifers are poorly described and are of questionable value for age determination, but this is our only independent clue to the age of the volcanogenic sediments. A ConiacianSantonian date (78 to 86 m.y.B.P., van Hinte, 1976; 82 to 87 m.y.B.P., Obradovich and Cobban, 1975) would be consistent with the radiometric dating of the underlying breccia $(82.1 \pm 8$ and $91.3 \pm 3$ m.y.B.P., Houghton et al., this volume).

We estimate that the main constructional activity on Vogel Seamount occurred between 94 and 88 m.y. ago, according to the more reliable of the radiometric ages; because the dated clasts may have been displaced from pre-existing volcanic units on the seamount by a latestage volcanic event, the late-stage volcanism may have occurred somewhat later than this.

A very rough check on the 88 to 94 m.y. age of Vogel Seamount can be made by using the 1.3-km depth of adjacent, flat-topped Rehoboth Seamount, assuming that the crest of Rehoboth Seamount was formed near sea level. Detrick et al. (1977) have shown that aseismic ridges and mid-plate volcanic chains subside along a curve like that of normally subsiding ocean crust. If Rehoboth, like Vogel, formed about 90 m.y. ago, the surrounding crust at the time of seamount formation was about $30 \mathrm{~m}$.y. old. Subsequent subsidence of ocean crust between ages of 30 and 120 m.y. was about $1.3 \mathrm{~km}$ (Tucholke and Vogt, this volume) or somewhat more, because of the sediment load imposed on the ocean crust surrounding, but not on, Rehoboth Seamount. Thus, the present summit depth of Rehoboth is consistent with an age of roughly 90 m.y., contemporaneous with Vogel, and with a present crustal age of $120 \mathrm{~m} . \mathrm{y}$. The seamount ages derived in this fashion are much too imprecise to discriminate between a "hot-spot" hypothesis (Vogel $\sim 10$ m.y. older than Nashville), and a hypothesis of simultaneous volcanism along a fracture.

Considering the available evidence, we estimate the age of Nashville at 80 to 94 m.y. and Vogel at 88 to 94 m.y. Vogel could be somewhat older than Nashville (perhaps up to $10 \mathrm{~m} . \mathrm{y}$. as predicted by Morgan's Mesozoic hot-spot model), but this conclusion certainly is not definitive. As the previous discussions indicate, there are ample margins of uncertainty, and both seamounts could be of the same age. Assuming that they are, the best pooled age estimate is about 89 m.y. (Figure 1). If volcanism formed the New England Seamount Chain about 89 m.y. ago, then Congress Seamount, which sits on crust about $87 \mathrm{~m}$.y. old and is the southeasternmost seamount along the New England Seamount trend, may have had a separate origin; but the 2 m.y. discrepancy is too small to be significant, considering the uncertainties in seamount and crustal ages.

Two other igneous provinces that some authors have considered to be part of the same magmatic system that formed the New England Seamounts are the White Mountain magma series to the northwest and the Corner Seamounts to the east (Figures 1 and 2). The White Mountain magmas fall into three age groups, all of which predate 89 m.y.B.P. (see review by Vogt, 1973; Foland and Faul, 1977).

The Corner Seamounts, although not explicitly dated, must be younger than the approximately 70 to 90 m.y. old crust on which they were constructed. In the Corner group, the larger northeastern seamounts first were thought to be located on anomaly 30 (McGregor and Krause, 1972); this would indicate a crustal age of around 66 m.y. (Tarling and Mitchell, 1976). More recently, Cande and Kristoffersen (1977) have reidentified anomalies in this area (see Vogt and Einwich, this volume), and extrapolation of their isochrons suggests that the larger northeastern members of the Corner Seamounts lie on crust of about the age of anomaly 33 (76 m.y.). The northeasternmost large seamount (1160 m summit depth; $35.3^{\circ} \mathrm{N}, 48^{\circ} \mathrm{W}$ ) has a relief of about 4 $\mathrm{km}$ above the surrounding basement. Another seamount $(2290 \mathrm{~m})$ lies at $35.5^{\circ} \mathrm{N}, 47.4^{\circ} \mathrm{W}$. The easternmost seamount that is high enough to rise distinctly above the lower-flank topography of the Mid-Atlantic Ridge $\left(35^{\circ} \mathrm{N}, 46^{\circ} \mathrm{W}\right.$, summit depth $\left.2340 \mathrm{~m}\right)$ has a relief of 2.5 to $3 \mathrm{~km}$ above the surrounding basement. According to the isochron chart of Cande and Kristoffersen (1977), this seamount is on crust about 63 m.y. old. According to an empirical relationship between seamount relief and crustal age at time of seamount formation (Vogt, 1974), it is likely that the eastern and northeastern Corner Seamounts are 5 to $10 \mathrm{~m}$.y. younger than the crust on which they erupted, and some probably are lower Tertiary. In contrast, the western Corner Seamounts are on crust of about the same age as the crust under Wyoming and Congress seamounts (Vogt and Einwich, this volume; Cande and Kristoffersen, 1977), and may be up to $90 \mathrm{~m}$.y. old. Thus, available evidence indicates only that the northeastern members of the Corner Seamount group are probably significantly younger than Nashville Seamount (80 to 94 m.y.B.P.).

On the basis of Leg 43 drilling results alone, it is not possible to resolve whether volcanism along the southeastern part of the New England Seamount Chain was essentially synchronous or migratory. However, if the White Mountain igneous province and the Corner Seamounts are considered to be part of the same magmatic system that formed the New England Seamounts, then some kind of migratory volcanism is required. 
If the Leg 43 data are interpreted within a hypothesis of "migratory volcanism" (whether caused by a stationary hot spot or a propagating fracture), the following conclusions can be drawn (Figure 1): (1)Migration rates of the order $1 \mathrm{~cm} /$ year or less are ruled out by the lack of a sufficiently great age difference between Vogel and Nashville seamounts. (2) Migration rates as high as $10 \mathrm{~cm} /$ year can be accommodated (but not proven) by the Nashville and Vogel data; but such rates are rather high for possible Cretaceous motion of the North America plate over the mantle (W.J. Morgan, personal communication, 1976). (3) Migration rates of about 4 $\mathrm{cm} /$ year are reasonable according to the hot-spot hypothesis and are consistent with but not proven by the drilling data. Our best estimate is that Vogel Seamount is up to $12 \mathrm{~m} . \mathrm{y}$. older than Nashville. This is strongly dependent on the $91.3 \pm 3$ m.y. radiometric age of the Vogel breccia, and a very tentative Coniacian-Santonian age for the overlying volcanogenic sediment. As noted earlier, a $4 \mathrm{~cm} /$ year migration rate leads to an $\sim 10 \mathrm{~m}$.y. age difference between the seamounts. (4) If all data are interpreted in a way that is favorable to a hot-spot hypothesis, a migration line of $4.3 \mathrm{~cm} /$ year (Model B, Figure 1) will pass through the Nashville and Vogel data, through Maestrichtian ash at DSDP Site 10 (possibly from the Corner Seamounts), and through the younger age group of the White Mountain Magma Series. According to the hot-spot hypothesis, however, we expect the line to pass through the older White Mountain ages (about 155 to 200 m.y.; Figure 1) because volcanism would not occur until a site had passed over the hot spot. Model A overcomes this difficulty with the plate moving relatively slowly $(1.5 \mathrm{~cm} /$ year $)$ over the mantle until about $110 \mathrm{~m} . y$. , and then speeding up to $3.4 \mathrm{~cm} /$ year (Figure 1). An acceleration of platemantle motion near $110 \mathrm{~m}$.y. was chosen only because the North America/Africa motion may have accelerated at that time by approximately a factor of two (Vogt and Einwich, this volume). One testable consequence of this model is the relatively stationary behavior of nearby portions of the Africa plate over the mantle during Cretaceous time. Independent evidence does place the Africa/mantle rotation pole not far from the New England Seamounts during the Cretaceous (W.J. Morgan, personal communication, 1977). Thus, a hot spot under the North America plate in the area of the seamounts would produce volcanic migration rates of the same order as the total spreading rate between the two plates, as approximated in Model A.

Although Model A represents the most reasonable "hot-spot" interpretation of the available data, we reiterate that the Leg 43 results, even in conjunction with other data, provide no decisive proof. Subsequent to Leg 43, Houghton et al. (1977) and Duncan and Houghton (1977) reported additional chemical and radiometric analyses of basalts dredged along the New England seamount chain. Considering all the data, those authors concluded that the eastern segment of the chain (Gregg to Nashville; Figures 1 and 2) was formed more or less simultaneously about $90 \mathrm{~m}$.y. ago, and seamounts of the western segment (Bear to Gosnold) become progressively older to the northwest. Interpreted by the hot-spot hypothesis, the older radiometric ages reported by Houghton et al. (1977) lend additional credence to Model A (Figure 1), which had predicted these ages (Bear, Retriever, Balanus, and Kelvin) reasonably well. It is more difficult to determine, however, whether the southeastern segment of the seamount chain formed simultaneously or during rapid plate motion. In either case, because the strike of the southeastern seamounts, unlike the northwestern seamounts, parallels adjacent fracture zones, it is possible that volcanism was fault-controlled (Figure 1; Uchupi et al., 1970; Le Pichon and Fox, 1971). If the radiometric ages on Gregg Seamount and seamounts farther southeast correctly date the origin of these features, then in a scheme of migratory volcanism, plate motion over the mantle is constrained to at least $6 \mathrm{~cm} /$ year. If the seamounts formed simultaneously, their formation could be related to fault-zone extension controlled by changes in plate motion. For example, changes in plate motion about 110 m.y. ago (Vogt and Einwich, this volume) may have attenuated volcanism through plate compression, and subsequent changes in plate motion about 90 m.y. ago could have resulted in extension and volcanism along the fault zone. A change in plate motion about 90 m.y.B.P. would have occurred in the Cretaceous quiet zone where there is little borehole control on crustal ages, and therefore is difficult to document. Such a change can be accommodated, however, by available crustal age data (see Figure 11 of Vogt and Einwich, this volume). The above scheme does not limit the nature of the source of magma generating the seamounts. For example, in a hot-spot model, attenuated volcanism could have occurred during the period of compression and then been masked by main-phase volcanic activity at 90 m.y.B.P. Effective documentation of this kind of seamount evolution would require drilling through the entire volcanic apron of a seamount to original oceanic crust.

\section{Duration of Seamount Volcanism}

A vexing problem for all hot-spot tests thus far is the duration of volcanism at a particular seamount or island. Of the boreholes along the New England (Sites 382 and 385) and Line Islands seamount chains (Jackson and Schlanger, 1976), none has penetrated through the seamount volcanics and into the original ocean crust. So unless evidence is adduced that the main, seamount-building volcanic phase was short-lived (a few million years or less) or relatively constant in duration, the available drill-hole data are of little value in determining the initiation of volcanism at a site. It is the initiation of volcanism that is relevant, because this dates the event that results in volcanism. In the hot-spot hypothesis, the initial volcanism marks the arrival of a patch of lithosphere over the sub-lithospheric hot spot. The hot-spot hypothesis - and other hypotheses of migratory volcanism, such as propagating fractures does not demand that volcanism cease the moment the volcano is moved from the hot-spot area by plate motion. In fact, it is reasonable to assume that residual 
magma chambers are carried along within the plate and continue to create surface volcanism, although in progressively diminishing intensity.

One approach to the problem is to examine the age range of volcanic formations that have been penetrated. If the observed range is great or highly variable, it is more likely (but not necessary) that the initiation of volcanism was substantially earlier than the oldest material recovered.

At Site 382 (Nashville Seamount), only about the top 8 meters of volcanogenic sediments is upper Campanian; all the sediment down to the upper breccia, and between the upper and lower breccias, is lower Campanian. We can conclude that (1) volcanism was still occurring but had almost ceased at the early/late Campanian boundary, and (2) most of the observed volcanism occured sometime during the early Campanian. Hence, from paleontological information the observed volcanism could have persisted up to about 4 m.y. The radiometric ages obtained on clasts in the lower breccia range from $79 \pm 4$ to $88.3 \pm 5.7$ m.y., but the oldest age is considered most reliable (Houghton et al., this volume). If we combine this age with the observation that volcanism had essentially ceased by the end of the early Campanian, the total duration of observed volcanism would range from a minimum of 9 m.y. (83 to 74 m.y.B.P.) up to about 20 m.y.

At Vogel Seamount, even less can be said about the duration of volcanism. The middle Maestrichtian sediments are not volcanogenic; so if the radiometric dates on Vogel Seamount (Houghton et al., this volume) are valid, less than about 20 or 25 m.y. elapsed between extrusion of clasts contained in the lower breccia $(91.3 \pm 3$ and $82.1 \pm 8$ m.y.) and the end of volcanism. If the volcaniclastic sediment above the breccia is indeed Coniacian-Santonian (as very tentatively suggested by study of agglutinated benthic foraminifers), then the duration of observed volcanism on Vogel Seamount could have been as little as a few million years or as much as 10 or $15 \mathrm{~m} . \mathrm{y}$. (we exclude a rejuvenation of magmatic activity suggested by the $21 \pm 3$ m.y. old sill (Houghton et al., this volume)).

At both Vogel and Nashville Seamounts, the vesicularity of the radiometrically dated basalt clasts indicates that the basalt was initially extruded at depths less than 0.5 to $1 \mathrm{~km}$ below sea level. Thus, the bulk of seamount construction occurred before extrusion of these basalts.

The occurrence of at least two episodes of intensified volcanic activity, as represented by breccia zones, is an interesting feature represented at both Sites 382 and 385. Unfortunately, our age dating is too imprecise to establish the time that elapsed between deposition of the upper and lower breccias at the sites. Although the intervening period of "relative quiescence" is represented by finer grained sediments, including some carbonates, the bulk of this sediment is volcaniclastic and could have been deposited in a geologically brief interval, less than a million years. In any case, the available radiometric and paleontologic ages suggest that the episodes were not separated by more than about 5 m.y. We cannot exclude the possibility that the two episodes were synchronous at the two sites; if they were, this would be incompatible with the hot-spot hypothesis, which requires migratory volcanism, and would argue for fault-controlled volcanism. Only the latest volcanic stages were cored, however, and an unknown number of additional episodes (coeval or migratory) lie below the lower breccias.

Because we did not completely penetrate the volcaniclastics and thereby date the onset of volcanism at either Site 382 or Site 385 , we know only that the volcanoes were active for at least a few m.y., and perhaps up to 10 or $20 \mathrm{~m} . \mathrm{y}$. Is it reasonable to assume that the initial volcanism at Vogel and Nashville seamounts was only a few million years older than the oldest material recovered? To answer this question, we can briefly review what is known about the duration of volcanism at other seamounts and islands. Mostly exposed, subaerially erupted rocks have been dated on oceanic islands. Thus, the derived ages are lower limits on duration of volcanism, because the earliest extrusives, erupted on the ocean floor, lie at great depth. No island has been drilled from top to bottom.

Baker (1973) has reviewed volcanic activity on islands in the South Atlantic. The duration of dated volcanism on Ascension (1.5 m.y.), Tristan da Cunha (0.1), Inacessible (2.9), and Nightingale (18) are lower limits, because these islands are still active in the geological sense. The duration at Gough (4 m.y.), St. Helena (7), Trinidade (3.5), and Fernando de Noronha (10) are more useful, because volcanism on those islands has apparently ceased.

North Atlantic age data have been reviewed by Ridley et al. (1974) for the Azores and by Anguita and Hernan (1975) for the Canary Islands. All of the Azores group can be classed as "still active," except Santa Maria, where two distinct episodes of volcanism (8.12 to 6.08 and $\sim 4.3 \mathrm{~m}$.y.B.P.) suggest a duration of about $4 \mathrm{~m}$.y. San Miguel (4.0 to 0.95 m.y.B.P.) is also essentially inactive, giving $3 \mathrm{~m} . \mathrm{y}$. for the duration of volcanism.

The Canary Islands are larger and have been active longer than most of the examples cited above. From radiometric dating on subaerial volcanics, it appears that Lanzarote, Fuerteventura, Gran Canaria, and Tenerife were active intermittently from the early or middle Miocene (19 to 15 m.y.B.P.) to the present. Episodes a few million years long are separated by lulls of similar length. These could be similar to the episodes observed at Nashville Seamount; but the Canary Islands' episodes do not appear to be synchronous from one island to the next (Anguita and Hernan, 1975). Gomera was active for about 10 m.y., but became extinct in the Pliocene. Hierro and LaPalma date only from 1 to 2 m.y.B.P. As the Canaries illustrate, volcanism at particular oceanic islands may continue for 10 to $20 \mathrm{~m} . \mathrm{y}$. or more, and it can be episodic (Anguita and Hernan, 1975). Despite these complexities, the ages of oldest subaerial volcanism in the Canaries appear to show a monotonic progression, from 0.75 m.y.B.P. on Hierro in the west to 19 m.y.B.P. on Lanzarote in the east. The observed migration of volcanism generally is consistent with an approximately $2.3 \mathrm{~cm} /$ year eastward 
motion of the Africa plate over a hot spot. Such a migration could never have been deduced from the youngest volcanism, since all islands except Gomera have been active in Recent time (Anguita and Hernan, 1975).

DSDP Site 397 represents the rare case of a drill hole penetrating through the base of volcanogenic formation, although the base of that formation is an erosional unconformity and may not contain the earliest volcanogenic sediments (Ryan et al., 1976). This site is situated about $100 \mathrm{~km}$ south-southeast of Gran Canaria and $150 \mathrm{~km}$ south-southwest of Fuerteventura, and the volcaniclastics recovered probably were derived from one of these islands. The oldest volcaniclastics recovered are conglomeratic horizons dating from latest early Miocene to early middle Miocene $(\sim 16-14$ m.y.B.P.). They "probably record the upward construction of submarine pedestal to a sufficient relief to provide a downslope longitudinal gradient" (Ryan et al., 1976, p. 22). Emplacement of these rocks "predates by about 3 million years the 13-14 m.y.B.P. shieldbuilding stage of the emerged Canary Islands" (Ryan et al., 1976), but it was approximately contemporaneous with the oldest measured ages on nearby Gran Canaria (16.1 m.y.) and Fuerteventura (16.6 m.y.). At Site 397, the conglomerates are overlain by ash layers apparently most concentrated in the middle upper Miocene $(\sim 5$ m.y. old), although a few were deposited in the early Pliocene. Thus, the borehole data depict a volcanic history whose timing is rather similar to that deduced from the dating of subaerial volcanics (Anguita and Hernan, 1975). Apparently, the initial construction of the island edifices occurred rapidly, within a few million years.

At Site 386, $90 \mathrm{~km}$ southeast of Bermuda, the borehole also penetrated entirely through a volcanogenic formation. Heavy mineral turbidites recording subaerial weathering of Bermuda appear in the upper middle to lower upper Eocene (46 to 42 m.y.) and continue through the upper Oligocene (26 to 22.5 m.y.); minor volcaniclastic debris and scattered volcanic ash continue into the lower or perhaps middle Miocene (22.5 to $15 \mathrm{~m} . \mathrm{y}$.). The results suggest that the principal Bermuda volcanoes had been constructed to and above sea level in a main, shield-building tholeiitic stage by about 45 m.y.B.P., and were largely leveled by erosion in the next 10 to $20 \mathrm{~m}$.y. Intrusion of lamprophyre dikes occurred in a distinct episode about 33 m.y.B.P. (Reynolds and Aumento, 1974). During the erosional period, some ash-producing volcanism may have occurred, but discrete ash layers were not found at Site 386 . Although the main, shield-building stage may have been short, the total span of volcanism probably exceeded 10 m.y. and may have exceeded 20 m.y.

No mid-plate volcanic chain has been more thoroughly studied than the Hawaiian chain, and none has provided a more convincing case for a stationary mantle hot spot (Morgan, 1971, 1972; Jackson, 1976). Although compared with most mid-plate chains the Hawaiian chain is anomalous in its productivity and the abundance of tholeiites, we are forced to lean on it as a standard of comparison. Jackson (1976) has reviewed the pertinent data. The tholeiitic shield-building stage of each Hawaiian volcanic edifice seems to last no more than 0.2 to $1 \mathrm{~m} . \mathrm{y}$. Some sporadic volcanic activity continues into the period of active shield erosion; late-stage basalts of this type are called "post-erosional" because they often occur extruded on erosional surfaces. The last of these post-erosional basalts may post-date the tholeiitic stage by 2 to 4 m.y. In the better known southeastern Hawaiian Islands, each volcanic edifice passes from a shield-building stage ( $99 \%$ of the total volume), through an alkalic stage, and finally to a nephelinitic post-erosional stage of activity before complete extinction.

Other volcanic chains in the Pacific are not so simple: in many areas, potassic basanites and nephelinites, similar to the post-erosional basalts on Hawaii, may be much younger than the volcanic edifices on which they occur (Jackson and Schlanger, 1976; Natland, 1976). Jackson (1976) indicates that it may be "possible that any release of pressure beneath any chain of preexisting volcanic edifices could initiate post-erosional volcanism of any age younger than the formation of the major shields." Experience from Hawaii and Samoa suggests that "dated rocks of strongly alkalic character are especially suspect in this regard."

Although tholeiitic basalts do not appear to be typical of most intraplate volcanic chains, there is always the disturbing possibility that late-stage alkali basalt has mantled an older, tholeiitic volcanic edifice. The basalts from the breccias at Sites $\mathbf{3 8 2}$ and $\mathbf{3 8 5}$ are highly alkalic, except for a single fragment (Site 382) which resembles a tholeiite (Houghton, this volume). We cannot exclude the possibility that ocean island tholeiites form the interiors of these seamounts, but data from numerous islands make this rather unlikely.

We can summarize the previous discussion as follows: (1)The total duration of volcanism at many oceanic islands appears to be in the range 3 to $20 \mathrm{~m}$.y., and occasionally is longer. These durations are comparable to those inferred for Vogel and Nashville seamounts. (2) However, as far as we are able to determine without drilling through a volcanic edifice, the main constructional phase may last only $1 \mathrm{~m} . \mathrm{y}$. or less (Hawaii [McDougall, 1971; Jackson, 1976]), or a few million years, as at the Canary Islands. (3) Sporadic igneous activity, volumetrically unimportant, may sometimes occur much later - for example, the nepheliniticbasanitic rocks in the southwest Pacific (Natland, 1976; Jackson and Schlanger, 1976) or the 21-m.y.-old tholeiitic sill at Site 385 on Vogel Seamount. (4) Episodic activity at a given locale, like that indicated by the two volcaniclastic breccia zones at Site 382 , has been reported elsewhere, for example, on most of the Canary Islands (Anguita and Hernan, 1975) and some of the Azores (Ridley et al., 1974). The episodes may be separated by a few million years. (5) Evidence from subaerial exposures of volcanic rocks on islands is in general agreement with DSDP borehole results. 
Although volcanic activity may continue more than ten million years at some mid-plate volcanic edifices, the main, constructional activity generally occurs within a span of a few million years. At Sites 382 and 385 we penetrated considerable thicknesses of volcaniclastic debris; the basaltic clasts in the breccias appear to have been extruded within a kilometer of sea level in the later part of the main constructional phase. We infer, therefore, that volcanism at Sites 382 and 385 probably did not begin more than a few million years before the time when these basalts erupted.

\section{COMPARISON OF THE NEW ENGLAND SEA- MOUNTS WITH THE LINE ISLANDS CHAIN}

In evaluating a possible "hot-spot" origin for the New England Seamounts, we can profit by reviewing the results of Leg 33, the only previous DSDP cruise having as a primary objective the testing of Morgan's (1972) hypothesis. The Line Islands chain examined on Leg 33 had been thought to be Paleogene or older like the New England Seamount Chain. Two sites (315 and 316) in the southern part of the Line Islands chain, plus an earlier site (165, Leg 17), should, according to the hot-spot model, have yielded substantial age differences: Site 316 is $1270 \mathrm{~km}$ southeast of Site 165. Like Sites 382 and 385 in the Atlantic, the Pacific "hot-spot test" left much to be desired. At none of the three Line Islands sites did the hole reach the bottom of the volcanogenic formation, so only the later volcanic events and the cessation of volcanism could be dated. All three Line Islands boreholes (like Site 385) failed to find fossiliferous sediment in contact with "island edifice" basalt. At Sites 165 and 315, 50 meters and 70 meters of barren sediment lay between the lowest datable horizon and basaltic basement; at Site 316 basalt was not reached, but was believed to lie no more than 75 meters below the bottom of the hole. The dates extrapolated by the shipboard party for the cessation of volcanism were 79 to 83 m.y.B.P. (Site 165), 85 m.y.B.P. (Site 315), and 81 to 83 m.y.B.P. (Site 316). Since these three dates were all similar, it was concluded that cessation of volcanism (and probably the beginning as well) was coeval along the Line Islands chain - thus disproving a hot-spot origin for the chain (Schlanger, Jackson, et al., 1974). But by the time the Leg 33 results were published in the Initial Reports volume, additional analysis and reinterpretation had cast doubt on this conclusion. Lanphere and Dalrymple (1976) concluded from K-Ar and fossil age data that there was no conclusive evidence that the Line Islands do not become younger from north to south. Applying the Cretaceous time scale of Obradovich and Cobban (1975) to Sites 315 and 165, Lanphere and Dalrymple obtained significantly older extrapolated basement ages than did Schlanger, Jackson et al. (1974).

In their regional synthesis of Leg 33, Jackson and Schlanger (1976) concluded, on the basis of available data, that the Line Islands chain appears to have "propagated in a direction of $S 37.5^{\circ} \mathrm{E}$ at an average rate of about $5.2 \mathrm{~cm} /$ year along en-echelon edifices built of materials much like those of the Samoan and Hawaiian chains." Jackson and Schlanger also estimated that the chain formed over the interval approximately between 128 and 80 m.y. ago, and that "present information does not disprove that the chain propagated at a regular rate as required by the Morgan (1972) hypothesis."

Scientific opinion thus progressed from initial rejection of the hot-spot hypothesis (Schlanger, Jackson, et al., 1974) to a neutral (Lanphere and Dalrymple, 1976) or even tentatively positive (Jackson and Schlanger, 1976) verdict. Nevertheless, a lack of unanimity is indicated by the conclusion, elsewhere in the Leg 33 Initial Reports (Schlanger, Jackson, et al., 1976), that from the results of Legs 33 and 17, cessation of flow-type volcanism was essentially coeval along the Line Islands chain, and that even if all errors favor the hot-spot hypothesis, unreasonable propagation rates of 12-21 $\mathrm{cm} /$ year would be required.

The Leg 33 data are significant to our drilling results on the New England Seamounts for the following reasons: (1) It appears possible that the Line Islands chain does exhibit a consistent age-distance relationship such as that demanded by the hot-spot hypothesis (Jackson and Schlanger, 1976). More or less systematic age gradients also have been documented for other chains, especially in the Pacific (Jackson, 1976, and references cited therein), and the concept thus remains plausible for the New England Seamounts. (2) Whether or not the New England and Line Island volcanoes were formed by hot spots, it appears that both chains are about the same age. If both chains formed coevally about 80 to 90 m.y. ago, a burst of Cretaceous midplate volcanism would be indicated. (3) If considered as hot-spot traces, the two chains potentially would record Pacific/mantle and America/mantle motion for most of Cretaceous time. (4) For both volcanic chains, the drillhole data are inadequate to conclusively test hypotheses for their origin. Conclusions are tentative and are certain to change with additional data. More drilling and sampling clearly is required, but for drilling to be decisive it is essential to penetrate the entire volcanic section and thereby date the initiation of volcanism. Such sampling presently appears to be the single most productive step in resolving the origin of the New England Seamounts and other linear seamount chains.

\section{ACKNOWLEDGMENTS}

We thank our colleagues on Leg 43 for stimulating discussions and for their efforts in the successful conduct of the cruise. We also thank A. Watts and R. Larson for critical review of the manuscript and for discussion and presentation of interpretations that may differ from those presented here. R. L. Houghton was particularly helpful in providing recent age data for the New England Seamounts, in discussions, and in review of the paper. P. Vogt gratefully acknowledges sabbatical leave support by Geologisk Institutt, University of Oslo, during preparation of this paper. B. Tucholke gratefully acknowledges support by NSF Grant 0CE-76-0238 while synthesizing the Leg 43 drilling results. 


\section{REFERENCES}

Anguita, F. and Hernan, F., 1975. A propagating fracture model versus a hot spot origin for the Canary Islands, Earth Planet. Sci. Lett., v. 27, p. 11-19.

Anonymous, 1973. North Atlantic Region 6, Standard Navy Ocean Area Regional Chart 6, Prototype Edition.

Baker, P. E., 1973. Islands of the South Atlantic. In Nairn, A. E. M., and Stehli, F. G. (Eds.), The ocean basins and margins, v. 1: The South Atlantic: New York (Plenum Press), p. 493-553.

Cande, S. C. and Kristoffersen, Y., 1977. Late Cretaceous magnetic anomalies in the North Atlantic, Earth Planet. Sci. Lett., v. 35, p. 215-224.

Coney, P. J., 1971. Cordilleran tectonic transitions and motion of the North American plate, Nature, v. 233, p. 462-465.

Detrick, R. S., Sclater, J. G., and Thiede, J., 1977. The subsidence of aseismic ridges, Earth Planet. Science Lett., v. 34, p. 185-196.

Duncan, R. A. and Houghton, R. L., 1977. Radiometric age dating of the New England Seamounts, Am. Geophys. Union, Fall Annual Meeting, San Francisco.

Foland, K. A. and Faul, H., 1977. Ages of the White Mountain intrusives-New Hampshire, Vermont and Maine, USA, $A m$. J. Sci., v. 277 , p. 888-904.

Houghton, R. L., 1978. Petrology and geochemistry of the New England Seamount Chain, Unpublished Ph.D., Thesis, Mass. Inst. Technology-Woods Hole Oceanographic Institution.

Houghton, R. L., Thompson, G., and Bryan, W. B., 1977. Petrological and geochemical studies of the New England Seamount Chain, $A G U$ Trans. v. 58, p. 530.

Jackson, E. D., 1976. Linear volcanic chains on the Pacific plate. In Sutton, G. H. et al. (Eds.), The Geophysics of the Pacific Ocean Basin and its margin, Geophys. Monograph 19, American Geophysical Union, p. 319-355.

Jackson, E. D. and Schlanger, S. O., 1976. Regional syntheses, Line Islands Chain, Tuamotu Island Chain, and Manihiki Plateau, Central Pacific Ocean. In Schlanger, S. O., Jackson, E. D., et al., Initial Reports of the Deep Sea Drilling Project, v. 33: Washington (U.S. Government Printing Office), p. 915-927.

Krasheninnikov, V. A., 1973. Cretaceous benthonic foraminifera, Leg 20, Deep Sea Drilling Project. In Heezen, B. C., MacGregor, I. D., et al., Initial Reports of the Deep Sea Drilling Project, v. 20: Washington (U.S. Government Printing Office), p. 205-219.

, 1974. Upper Cretaceous benthonic agglutinated foraminifera, Leg 27 of the Deep Sea Drilling Project. In Veevers, J. J., Heirtzler, J. R., et al., Initial Reports of the Deep Sea Drilling Project, v. 27: Washington (U.S. Government Printing Office), p. 631-663.

Lanphere, M. A. and Dalrymple, G. B., 1976. K-Ar ages of basalts from DSDP Leg 33: Sites 315 (Line Islands) and 317 (Manihiki Plateau). In Schlanger, S. O., Jackson, E. D., et al., Initial Reports of the Deep Sea Drilling Project, v. 33: Washington (U.S. Government Printing Office), p. 649-653.
Le Pichon, X. and Fox, P. J., 1971. Marginal offsets, fracture zones, and the early opening of the North Atlantic, $J$. Geophys. Res., v. 76, p. 6294-6308.

McDougall, I., 1971. Volcanic island chains and sea-floor spreading, Nature, v. 231, p. 141-144.

McGregor, B. A. and Krause, D. C., 1972. Evolution of the sea floor in the Corner Seamounts area, J. Geophys. Res., v. 77 , p. $2525-2534$.

Moore, J. G., 1965. Properties of Hawaiian submarine basalts, Geol. Soc. Am. Spec. Paper 82.

Morgan, W. J., 1972. Deep mantle convection plumes and plate motions, Am. Assoc. Petrol. Geol. Bull., v. 56, p. 203-213. 1971. Convection plumes in the lower mantle, Nature, v. 230.

Natland, J. H., 1976. Petrology of volcanic rocks dredged from seamounts in the Line Islands. In Schlanger, S. O., Jackson, E. D., et al., Initial Reports of the Deep Sea Drilling Project, v. 33: Washington (U.S. Government Printing Office), p. 749-777.

Obradovich, J. D. and Cobban, W. A., 1975. A time-scale for the Late Cretaceous of the western interior of North America. In Caldwell, W. G. (Ed.), The Cretaceous System in The Western Interior of North America. Geol. Assoc. Canada Spec. Paper 13, p. 31-54.

Peterson, M. N. A., Edgar, N. T., et al., 1970. Initial Reports of the Deep Sea Drilling Project, v. 2: Washington (U.S. Government Printing Office).

Reynolds, P. H. and Aumento, F., 1974. Deep Drill 1972: Potassium-argon dating of Bermuda drill core, Canadian J. Earth Sci., v. 11, p. 1269-1273.

Ridley, W. I., Watkins, N. D., and MacFarlane, D. J., 1974. The oceanic Islands: Azores. In Nairn, A. E. M., and Stehli, F. G. (Eds.), The Ocean Basins and Margins: New York (Plenum Press), v. 1, p. 445-483.

Ryan, W. B. F., et al., 1976. Passive continental Margins: Geotimes, v. 21(10), p. 21-24.

Schlanger, S. O., Jackson, E. D. et al., 1974. Leg 33, Deep Sea Drilling Project: Testing a hot-spot theory: Geotimes, v. $19(3)$, p. $16-20$.

1976. Initial Reports of the Deep Sea Drilling Proect, v. 33: Washington (U. S. Government Printing Office).

Schouten, H. and Klitgord, K. D., 1977. Map showing Mesozoic magnetic anomalies: western North Atlantic, U.S. Geol. Survey Misc. Field Studies, Map MF915, Scale 1:2 million.

Tarling, D. H., and Mitchell, J. G., 1976. Revised Cenozoic polarity time scale, Geology, v. 4, p. 133-136.

Uchupi, E., Phillips, J. D., and Prada, K. E., 1970. Origin and structure of the New England Seamount Chain, Deep-Sea Res., v. 17, p. 483-494.

van Hinte, J. E., 1976. A Cretaceous time scale, Am. Assoc. Petrol. Geol. Bull., v. 60, p. 498-516.

Vogt, P. R., 1973. Early events in the opening of the North Atlantic. In Tarling, D. H. and Runcorn, S. K. (Eds.), Implications of continental drift to the earth sciences, v. 2: London (Academic Press), p. 693-712. , 1974. Volcano height and plate thickness, Earth Planet. Sci. Lett., v. 23, p. 337-348. 